\title{
Supplemental $\beta$-carotene increases IgA-secreting cells in mammary gland and IgA transfer from milk to neonatal mice
}

\author{
Yoshitaka Nishiyama, Miki Sugimoto, Shuntaro Ikeda and Shinichi Kume* \\ Graduate School of Agriculture, Kyoto University, Kitashirakawa Oiwake-cho, Sakyo-ku, Kyoto 606-8502, Japan
}

(Received 6 April 2010 - Revised 2 July 2010 - Accepted 5 July 2010 - First published online 23 August 2010)

\begin{abstract}
Mortality of neonates continues to be a major problem in humans and animals. IgA provides protection against microbial antigens at mucosal surfaces. Although $\beta$-carotene supplementation has been expected to enhance retinoic acid-mediated immune response in neonates, the exact mechanism by which $\beta$-carotene enhances IgA production is still unclear. We investigated the effect of supplemental $\beta$-carotene for maternal mice during pregnancy and lactation on IgA antibody-secreting cells (ASC) in mammary gland and guts and on IgA transfer from milk to neonatal mice. Pregnant mice were fed untreated or $50 \mathrm{mg} / \mathrm{kg} \beta$-carotene-supplemented diets from $6.5 \mathrm{~d}$ postcoitus (dpc) to $14 \mathrm{~d}$ postpartum (dpp). Supplemental $\beta$-carotene increased the numbers of IgA ASC in mammary gland $(P<0 \cdot 05)$ and ileum $(P<0 \cdot 001)$, and also mRNA expression of IgA C-region in ileum $(P<0.05)$ of maternal mice at $14 \mathrm{dpp}$, but few IgA ASC were detected in mammary gland at $17.5 \mathrm{dpc}$. IgA concentration in stomach contents, which represents milk IgA level, was significantly higher $(P<0 \cdot 01)$ in neonatal mice born to $\beta$-carotene-supplemented mothers at 7 and $14 \mathrm{dpp}$, and IgA concentration in serum, stomach contents and faeces increased $(P<0 \cdot 001)$ drastically with age. These results suggest that $\beta$-carotene supplementation for maternal mice during pregnancy and lactation is useful for enhancing IgA transfer from maternal milk to neonates owing to the increase in IgA ASC in mammary gland and ileum during lactation.
\end{abstract}

Key words: Supplemental $\beta$-carotene: Mammary gland: IgA transfer: Neonatal mice

Mortality and morbidity of neonates continue to be major problems in humans and animals, and their most common disease is diarrhoea. Supplemental vitamin A and $\beta$-carotene enhance the immune system in neonates, and $\beta$-carotene has pro-vitamin A activity ${ }^{(1-5)}$. Vitamin $\mathrm{A}$ deficiency is associated with an increased risk of death from common childhood infections, and supplementation of vitamin A decreases diarrhoea and mortality in malnourished children $^{(6,7)}$. Additionally, $\beta$-carotene-deficient calves were found to have a higher incidence of diarrhoea and mortality in the first week of life ${ }^{(8,9)}$. Foods containing pro-vitamin A carotenoids are the primary source of vita$\min A$, and $\beta$-carotene is abundant in some vegetables and fruits ${ }^{(10,11)}$. Because animals are not able to synthesise retinoids de novo ${ }^{(11)}$, supplementation of $\beta$-caroteneenriched foods may be effective to enhance the immune system in humans and animals.

Passive immunity is critical to the survival and health of neonates, and colostrum or milk is a source of nutrients and immune components for neonates. IgA is the most abundant Ig isotype in mucosal secretions and provides protection against microbial antigens at mucosal surfaces $^{(6,12-14)}$. IgA antibodies produced from IgA antibody-secreting cells (ASC) in mammary glands are secreted mainly as dimers after incorporation of the $J$ chain and association with a transmembrane epithelial glycoprotein known as polymeric-Ig receptor ${ }^{(12,15)}$. IgA antibodies in milk are specific for antigens of the intestinal microflora and act to limit penetration of commensal intestinal bacteria through the neonatal intestinal epithelium ${ }^{(16,17)}$. Therefore, passive immune protection of the newborn gastrointestinal tract is dependent on an active process of IgA ASC accumulation in the lactating mammary gland of the mother ${ }^{(18)}$.

The gut-associated lymphoid tissue is the largest immunological tissue in the body. Peyer's patches are the main site for the generation of $\operatorname{IgA}^{+} \mathrm{B}$ cells, and plasmablasts differentiated by $\operatorname{IgA}^{+} \mathrm{B}$ cells home preferentially to the gut lamina propria through the thoracic duct and blood ${ }^{(6,12-14)}$. Recent studies ${ }^{(19,20)}$ showed that vitamin A metabolite, all-trans retinoic acid (RA), plays important roles in gut immunity and that RA is necessary for the imprinting of gut-homing specificity on $\mathrm{T}$ cells and the induction of gut-homing receptors on B cells and IgA ASC. Several effects of carotenoids are thought to be mediated by their

Abbreviations: ASC, antibody-secreting cells; dpc, days postcoitus; dpp, days postpartum; RA, retinoic acid. 
metabolism to vitamin A and subsequent mediation of RA receptor and retinoid $\mathrm{X}$ receptor response pathways ${ }^{(21)}$. Mice and rats efficiently convert $\beta$-carotene to vitamin $\mathrm{A}$ but absorb carotenoids intact only when they are provided in the diet at supraphysiological levels ${ }^{(10)}$. However, the exact mechanism of $\beta$-carotene for enhancing IgA transfer from mothers to neonates is still unclear, although $\beta$ carotene supplementation has been expected to enhance RA-mediated immune response in neonatal mice.

We investigated the effect of supplemental $\beta$-carotene for maternal mice during pregnancy and lactation on the number of IgA ASC and mRNA expression of IgA C-region in mammary gland and guts and on IgA transfer from maternal milk to neonatal mice. The present study demonstrated that $\beta$-carotene supplementation for maternal mice during pregnancy and lactation is effective to increase the number of IgA ASC in mammary gland and ileum and of milk IgA during lactation, and that the effects may be mainly due to the RA-mediated immune response. Additionally, most IgA in neonatal mice may be derived from milk IgA and $\beta$-carotene supplementation enhances IgA transfer from maternal milk to neonatal mice.

\section{Materials and methods}

\section{Animals and diets}

Pregnant ICR mice ( $n$ 28) were purchased from Clea Japan (Tokyo, Japan). They were housed in polycarbonate cages and maintained in an air-conditioned room $\left(24 \pm 2^{\circ} \mathrm{C}\right)$ under controlled lighting conditions (light-dark cycle, 14:10 h). All mice were allowed free access to water and treated in accordance with 'Regulation on Animal Experimentation at Kyoto University' (Animal Research Committee, Kyoto University, revised 2007).

Maternal mice were fed untreated (control group) or $50 \mathrm{mg} / \mathrm{kg} \quad \beta$-carotene-supplemented ( $\beta$-carotene group) diets from $6.5 \mathrm{~d}$ postcoitus $(\mathrm{dpc})$ to $14 \mathrm{~d}$ postpartum (dpp). The diets in the control group contained a vitamin mix, but $\beta$-carotene was not detected in the vitamin mix. Seven maternal mice from each group were dissected at $17 \cdot 5 \mathrm{dpc}$ (maternal mice during pregnancy) and $14 \mathrm{dpp}$ (maternal mice during lactation). At birth, the average litter sizes of mice born from control and $\beta$-carotene groups were 13.9 and $15 \cdot 0$, respectively, and all neonatal mice were used in the experiment. All the neonatal mice were alive by $7 \mathrm{dpp}$, and subsets of neonatal mice in each group, except five female and five male neonatal mice born to each mother, were dissected at $7 \mathrm{dpp}$. Then, five female and five male neonatal mice born to each mother were dissected at $14 \mathrm{dpp}$.

\section{Sample collection}

Body weights of maternal mice before birth and food intake of maternal mice throughout the experiment were measured at 10.00 hours every day. Body weights of neonatal mice were measured at 10.00 hours every day. Blood samples from maternal mice at $17.5 \mathrm{dpc}$ and $14 \mathrm{dpp}$ were obtained by cardiac puncture under anaesthesia with Avertin (2,2,2-tribromoethanol; Sigma-Aldrich Chemical, St Louis, MO, USA), and then mammary gland, jejunum and ileum were removed, immediately frozen in dry icecooled isopentane (2-methylbutane; Wako Pure Chemicals, Osaka, Japan) for immunohistochemical analysis or frozen in liquid $\mathrm{N}_{2}$ and stored at $-80^{\circ} \mathrm{C}$ for semi-quantitative RT-PCR. Blood samples from neonatal mice at 7 and $14 \mathrm{dpp}$ were obtained by incising their hearts and collecting with haematocrit tubes under anaesthesia with Avertin, and then small intestine, stomach contents and rectum faeces were rapidly removed. At $7 \mathrm{dpp}$, samples of blood, small intestine, stomach contents and rectum faeces of neonatal mice born to each mother were pooled, and the samples were separately pooled for female or male neonatal mice born to each mother at $14 \mathrm{dpp}$. The samples of small intestine were frozen in dry ice-cooled isopentane for immunohistochemical analysis or frozen in liquid $\mathrm{N}_{2}$ and stored at $-80^{\circ} \mathrm{C}$ for IgA analysis and semi-quantitative RT-PCR. The samples of stomach contents and rectum faeces were stored at $-20^{\circ} \mathrm{C}$ until IgA analysis.

\section{IgA immunoassay}

Blood samples from maternal or neonatal mice were left to stand at room temperature for $1 \mathrm{~h}$ or $30 \mathrm{~min}$ and then centrifuged at $3000 \mathrm{rpm}$ for $15 \mathrm{~min}$ or $10000 \mathrm{rpm}$ for $5 \mathrm{~min}$, respectively. Serum was fractionated for IgA analysis. Stomach contents and rectum faeces were thawed, strongly vortexed in cold PBS containing protease inhibitor (Complete Mini; Roche, Basel, Switzerland) and centrifuged at $15000 \mathrm{rpm}$ for $20 \mathrm{~min}$ at $4^{\circ} \mathrm{C}$. Small intestine was homogenised using Sample Grinding Kit (GE Healthcare, Piscataway, NJ, USA) according to the manufacturer's instructions and centrifuged at $15000 \mathrm{rpm}$ for $10 \mathrm{~min}$ at $4^{\circ} \mathrm{C}$. Each supernatant was fractionated for IgA analysis.

IgA concentration was measured using the Mouse IgA ELISA Quantitation Kit (Bethyl Laboratories, Montgomery, TX, USA) and ELISA Starter Accessory Package (Bethyl Laboratories) according to the manufacturer's instructions. Plates obtained from the procedures were read at 450 and $620 \mathrm{~nm}$ with a Microplate Reader (Multiskan FC; Thermo Fisher Scientific, Waltham, MA, USA).

\section{Immunohistochemical analysis}

Fresh frozen sections ( $6 \mu \mathrm{m}$ thick) mounted on glass slides precoated with 3-aminopropyltriethoxysilane (Aldrich Chemical, Milwaukee, WI, USA) were fixed in 10\% neutralbuffered formalin (Wako Pure Chemicals) for $10 \mathrm{~min}$ at room temperature. After washing in PBS ( $\mathrm{pH} 7 \cdot 4$ ), the sections were incubated with $1 \%$ bovine serum albumin and $5 \%$ normal donkey serum in PBS containing $0.02 \%$ 
Tween-20 (blocking solution) for $20 \mathrm{~min}$, successively with rabbit anti-mouse IgA (1:400 in the blocking solution; Open Biosystems, Huntsville, AL, USA) for $2 \mathrm{~h}$ at room temperature. After washing in PBS containing 0.02\% Tween-20, the sections were incubated with Alexa fluor 555 donkey anti-rabbit IgG (1:500 in the blocking solution; Invitrogen, Carlsbad, CA, USA) for $90 \mathrm{~min}$ at room temperature. The sections were washed in PBS containing 0.02\% Tween-20, mounted with glycerol (Wako Pure Chemicals) and then examined under a confocal laser scanning microscope (FV300; Olympus, Tokyo, Japan). The resulting images were analysed by ImageJ software (National Institute of Health, Bethesda, MD, USA).

The IgA-positive cells in mammary gland were counted in eight randomised fields from each mouse and represented as IgA ASC/field of view. Those in jejunum and ileum were counted in lamina propria of villi in five to eight randomised villi from each mouse and represented as IgA ASC/unit area of lamina propria of villi (unit $=10000 \mu \mathrm{m}^{2}$ ).

\section{Semi-quantitative $R T-P C R$}

The mRNA expression of IgA C-region in the tissue was examined by semi-quantitative RT-PCR. Total RNA was extracted using an RNeasy mini kit (Qiagen, Maryland, CA, USA). Complementary DNA was synthesised with oligo (dT) primer using an SuperScriptIII First-Strand Synthesis System for RT-PCR (Invitrogen) from $4 \mu \mathrm{g}$ RNA of each sample. The PCR was performed using Pt PCR SuperMix kit (Invitrogen). The primer pairs for IgA C-region were as follows: forward: 5'-TGCACAGTTACCCATCCTGA-3', reverse: 5'-GCACCAGCACTTCTTTAGGG-3'. The PCR procedure was as follows: after $95^{\circ} \mathrm{C}$ for $7 \mathrm{~min}$ to denature DNA, PCR was performed for thirty-five cycles at $95^{\circ} \mathrm{C}$ for $1 \mathrm{~min}, 53^{\circ} \mathrm{C}$ for $1 \mathrm{~min}, 72^{\circ} \mathrm{C}$ for $1 \mathrm{~min}$, then for thirty cycles for most tissues of maternal mice or thirty-five cycles for mammary gland of pregnant mice and intestine of neonatal mice at $72^{\circ} \mathrm{C}$ for $5 \mathrm{~min}$. The PCR products were electrophoresed in $2 \%$ agarose gel and stained with $1 \mu \mathrm{g} / \mathrm{ml}$ ethidium bromide solution. After electrophoresis, the gels were recorded with a digital recorder and then mRNA expression levels were semi-quantified using Image software. The relative abundance of specific mRNA was normalised by the abundance of glyceraldehyde-3-phosphate dehydrogenase mRNA. The primer pairs for glyceraldehyde-3-phosphate dehydrogenase were as follows: forward: 5'-GGGTGGAGCCAAACGGGTC-3', reverse: 5'-GGAGTTGCTGTTGAAGTCGC- $3^{\prime}$. The PCR procedure was as follows: after $95^{\circ} \mathrm{C}$ for $7 \mathrm{~min}$ to denature DNA, PCR was performed for twenty-five cycles at $95^{\circ} \mathrm{C}$ for $1 \mathrm{~min}, 59^{\circ} \mathrm{C}$ for $1 \mathrm{~min}$ and $72^{\circ} \mathrm{C}$ for $1 \mathrm{~min}$ for tissues of maternal mice or thirty cycles for intestine of neonatal mice. The final extension step was performed at $72^{\circ} \mathrm{C}$ for $5 \mathrm{~min}$.

\section{Statistics}

Data are expressed as mean values with their standard errors. Data from body weight and food intake were analysed by least squares ANOVA using the general linear model procedure of Statistical Analysis Systems (SAS Institute, Cary, NC, USA) ${ }^{(22)}$. The model was as follows:

$$
Y_{i j k}=\mu+T_{i}+M_{(i) j}+D_{k}+T D_{i k}+e_{i j k}
$$

where $\mu$ is the overall mean, $T_{i}$ is the effect of treatment, $M_{(i) j}$ is the random variable of mice nested in treatment, $D_{k}$ is the effect of sampling day, $T D_{i k}$ is the interactions and $e_{i j k}$ is the residuals. The general linear model procedure of Statistical Analysis Systems ${ }^{(22)}$ was used to analyse the effects of treatment on some variables in maternal mice or neonatal mice at $7 \mathrm{dpp}$, the effects of treatment, sex and their interaction on some variables in neonatal mice at $14 \mathrm{dpp}$ and the effect of age on some variables in neonatal mice. Significance was declared at $P<0 \cdot 05$.
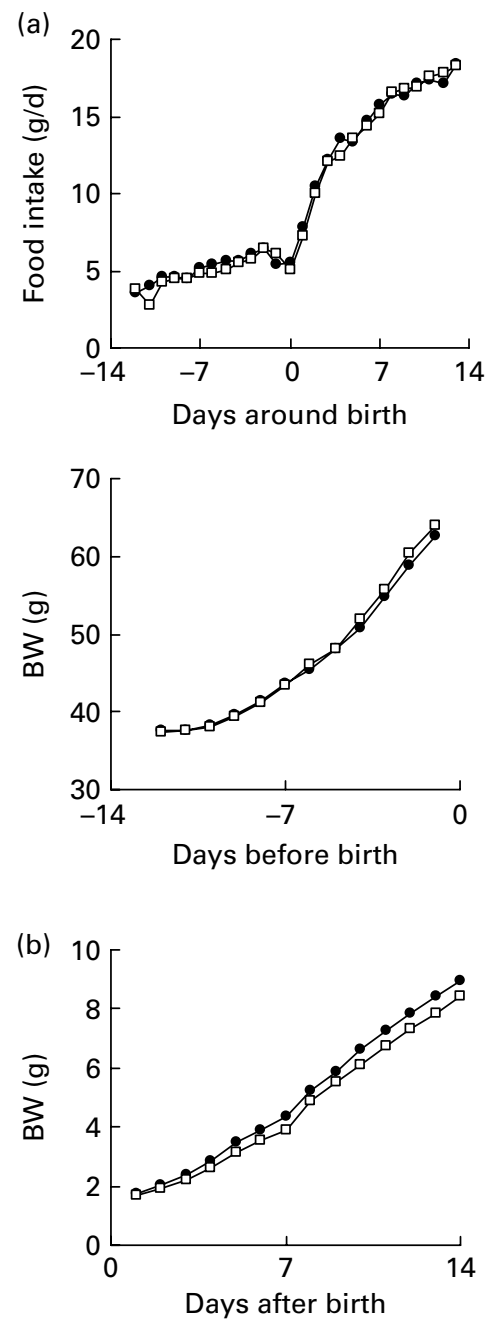

Fig. 1. Least squares means of (a) body weights (BW) and food intake of maternal mice in control $(\bullet)$ and $\beta$-carotene groups $(O)$, and (b) BW of their neonatal mice in control $(\bullet)$ and $\beta$-carotene groups $(O)$. 


\section{Results}

\section{Body weight and food intake}

Body weight gains and food intake of maternal mice dissected at $14 \mathrm{dpp}$ as well as those of maternal mice dissected at $17.5 \mathrm{dpc}$ (data not shown) were similar between the groups (Fig. 1). In maternal mice, body weights increased $(P<0.001)$ during pregnancy and food intake increased $(P<0.001)$ rapidly after birth. Body weight gains of neonatal mice were similar between the groups, but body weights at 7 and $14 \mathrm{dpp}$ were significantly lower $(P<0.01)$ in neonatal mice born to $\beta$-carotene-supplemented mothers.

\section{IgA concentration in serum and tissues}

Serum IgA concentrations of maternal mice at $17 \cdot 5 \mathrm{dpc}$ and 14 dpp were not affected by treatment (Table 1). Compared with IgA concentration in serum of neonatal mice at $7 \mathrm{dpp}$, serum IgA concentration of maternal mice was about 1000 times higher. IgA concentrations in stomach contents of neonatal mice born to $\beta$-carotene-supplemented mothers were significantly higher $(P<0.01)$ than those of control mice at 7 and $14 \mathrm{dpp}$. Although no significant differences were obtained in serum, small intestine and faeces of neonatal mice, their IgA concentrations were slightly higher in mice born to $\beta$-carotene-supplemented mothers at day 14 (Table 1). Compared with IgA concentrations of neonatal mice at $7 \mathrm{dpp}$, IgA concentrations in serum $(P<0.001)$, stomach contents $(P<0.001)$, small intestine $(P<0.01)$ and faeces $(P<0.001)$ increased drastically at $14 \mathrm{dpp}$, but their IgA concentrations were not affected by sex.

\section{IgA antibody-secreting cells in tissues}

The numbers of IgA ASC in jejunum and ileum of maternal mice at $17.5 \mathrm{dpc}$ were not affected by treatment (Table 2).
The numbers of IgA ASC in mammary gland $(P<0.05)$ and ileum $(P<0.001)$ of maternal mice fed $\beta$-carotene were significantly higher than those of control mice at $14 \mathrm{dpp}$, but there was no significant difference in jejunum. Few $(>2)$ IgA ASC were detected in mammary gland of maternal mice at $17.5 \mathrm{dpc}$ and jejunum and ileum of neonatal mice at $14 \mathrm{dpp}$ in each group (data not shown).

\section{Expression of mRNA in tissues}

The mRNA expression of IgA C-region in ileum was significantly higher $(P<0.05)$ in maternal mice fed $\beta$-carotene at $14 \mathrm{dpp}$, but there were no differences in the mRNA expression of IgA C-region in mammary gland and jejunum (Table 2). At $17.5 \mathrm{dpc}$, there were no significant differences in mRNA expression of IgA C-region in mammary gland, jejunum and ileum of maternal mice between the groups. The mRNA expression of IgA C-region in jejunum significantly decreased $(P<0.01)$ in neonatal mice born to $\beta$-carotene-supplemented mothers at $14 \mathrm{dpp}$, but this was not affected by sex.

\section{Discussion}

The importance of adequate consumption of high-quality colostrum or milk for acquisition of optimal nutrition and passive immunity is widely recognised in neonates ${ }^{(1,23)}$. In the present study, the nutritional status in maternal and neonatal mice was thought to be normal because the patterns of food intake and growth rate of maternal or neonatal mice agree with those in previous reports ${ }^{(16,24)}$ and low body weights in neonatal mice born to $\beta$-carotenesupplemented mothers may be due to more competition for available milk. Supplemental $\beta$-carotene for maternal mice during pregnancy and lactation increased the number of maternal IgA ASC in mammary gland during lactation, although very few IgA ASC were detected during

Table 1. IgA concentration $(\mu \mathrm{g} / \mathrm{g})$ in serum of maternal mice at $17.5 \mathrm{~d}$ postcoitus $(\mathrm{dpc})$ and $14 \mathrm{~d}$ postpartum $(\mathrm{dpp})$, and IgA concentration $(\mu \mathrm{g} / \mathrm{g})$ in serum, stomach contents, intestine and faeces of neonatal mice at 7 and $14 \mathrm{dpp}$ in control and $\beta$-carotene groups

(Mean values with their standard errors)

\begin{tabular}{|c|c|c|c|c|c|c|}
\hline & \multirow[b]{2}{*}{ Days } & \multicolumn{2}{|c|}{ Control } & \multicolumn{2}{|c|}{$\beta$-Carotene } & \multirow[b]{2}{*}{$P$} \\
\hline & & Mean & SE & Mean & SE & \\
\hline \multicolumn{7}{|l|}{ Mother } \\
\hline \multirow[t]{2}{*}{ Serum } & $17.5 \mathrm{dpc}$ & 630 & 120 & 690 & 121 & 0.713 \\
\hline & 14 dpp & 479 & 79 & 715 & 102 & 0.102 \\
\hline \multicolumn{7}{|l|}{ Neonate } \\
\hline \multirow[t]{2}{*}{ Serum } & $7 \mathrm{dpp}$ & 0.38 & 0.03 & 0.42 & 0.03 & 0.366 \\
\hline & $14 \mathrm{dpp}$ & 2.35 & 0.21 & $2 \cdot 77$ & 0.28 & 0.254 \\
\hline \multirow[t]{2}{*}{ Stomach } & $7 \mathrm{dpp}$ & $12 \cdot 2$ & $2 \cdot 3$ & $26 \cdot 6$ & 3.5 & 0.008 \\
\hline & $14 \mathrm{dpp}$ & $38 \cdot 8$ & 4.5 & $73 \cdot 3$ & 9.1 & 0.003 \\
\hline \multirow[t]{2}{*}{ Intestine } & $7 \mathrm{dpp}$ & 28.0 & $9 \cdot 7$ & 34.0 & $10 \cdot 6$ & 0.721 \\
\hline & $14 \mathrm{dpp}$ & $84 \cdot 1$ & $18 \cdot 8$ & 129.6 & 22.4 & 0.145 \\
\hline \multirow[t]{2}{*}{ Faeces } & $7 \mathrm{dpp}$ & $71 \cdot 2$ & $25 \cdot 8$ & 71.4 & $19 \cdot 1$ & 0.973 \\
\hline & $14 \mathrm{dpp}$ & 356 & 69 & 567 & 110 & 0.145 \\
\hline
\end{tabular}


Table 2. Numbers of IgA antibody-secreting cells (ASC) and mRNA expression of IgA C-region in mammary gland, jejunum and ileum of maternal mice at $17.5 \mathrm{~d}$ postcoitus (dpc) and $14 \mathrm{~d}$ postpartum (dpp), and the mRNA expression of IgA $C$-region in jejunum and ileum of neonatal mice at $14 \mathrm{dpp}$ in control and $\beta$-carotene groups

(Mean values with their standard errors)

\begin{tabular}{|c|c|c|c|c|c|c|}
\hline & \multirow[b]{2}{*}{ Days } & \multicolumn{2}{|c|}{ Control } & \multicolumn{2}{|c|}{$\beta$-Carotene } & \multirow[b]{2}{*}{$P$} \\
\hline & & Mean & SE & Mean & SE & \\
\hline \multicolumn{7}{|c|}{ Numbers of IgA ASC } \\
\hline Mammary gland & 14 dpp & $8 \cdot 8$ & 0.7 & $12 \cdot 0$ & $1 \cdot 0$ & 0.018 \\
\hline \multirow[t]{2}{*}{ Jejunum } & $17 \cdot 5 \mathrm{dpc}$ & $7 \cdot 5$ & 0.4 & 8.0 & 0.3 & 0.192 \\
\hline & $14 \mathrm{dpp}$ & $7 \cdot 7$ & 0.6 & $8 \cdot 8$ & $1 \cdot 0$ & 0.313 \\
\hline \multirow[t]{2}{*}{ Ileum } & $17.5 \mathrm{dpc}$ & $7 \cdot 6$ & 0.5 & 8.0 & 0.2 & 0.463 \\
\hline & $14 \mathrm{dpp}$ & 7.0 & 0.4 & 9.6 & 0.5 & $<0.001$ \\
\hline \multirow{2}{*}{\multicolumn{7}{|c|}{$\begin{array}{l}\text { IgA mRNA/GAPDH } \\
\text { Mother }\end{array}$}} \\
\hline & & & & & & \\
\hline \multirow{2}{*}{ Mammary gland } & $17.5 \mathrm{dpc}$ & 0.86 & 0.07 & 0.94 & 0.12 & 0.572 \\
\hline & $14 \mathrm{dpp}$ & 0.63 & 0.04 & 0.71 & 0.03 & 0.150 \\
\hline \multirow[t]{2}{*}{ Jejunum } & $17.5 \mathrm{dpc}$ & 1.01 & 0.09 & 1.04 & 0.05 & 0.749 \\
\hline & $14 \mathrm{dpp}$ & 1.38 & 0.17 & 1.68 & 0.28 & 0.169 \\
\hline \multirow[t]{2}{*}{ Ileum } & $17.5 \mathrm{dpc}$ & 0.78 & $0 \cdot 10$ & 0.90 & 0.04 & 0.314 \\
\hline & 14 dpp & 0.82 & 0.08 & 1.29 & 0.17 & 0.034 \\
\hline \multicolumn{7}{|l|}{ Neonate } \\
\hline Jejunum & $14 \mathrm{dpp}$ & 1.29 & 0.09 & 0.95 & 0.08 & 0.007 \\
\hline Ileum & $14 \mathrm{dpp}$ & 1.53 & 0.21 & 1.73 & 0.29 & 0.582 \\
\hline
\end{tabular}

GAPDH, glyceraldehyde-3-phosphate dehydrogenase.

* The numbers of IgA ASC in mammary gland were counted in eight randomised fields from each mouse, and values in jejunum and ileum were counted in lamina propria of villi in five to eight randomised villi from each mouse. The mRNA expression is represented relative to the IgA C-region mRNA expression normalised by abundance of GAPDH mRNA.

pregnancy. Additionally, higher IgA concentration in stomach contents, which represented milk IgA level ${ }^{(25)}$, was observed in neonatal mice born to $\beta$-carotene-supplemented mothers.

The majority of Ig in murine milk is IgA, and milk IgA provides protection against microbial antigens in neonates ${ }^{(15)}$. Gut-associated lymphoid tissue dendritic cells rely on RA to induce IgA class switching, and RA is essential for the imprinting of gut-homing receptors on $\mathrm{T}$ and $\mathrm{B}$ cells ${ }^{(19,20)}$. Supplementation of vitamin $\mathrm{A}$ and carotenoids affects the immune cell function during ontogenesis, and higher values of total serum $\operatorname{Ig} G$ were found in $\beta$-carotene-enriched $(300 \mathrm{mg} / \mathrm{kg})$ neonatal mice on day $7^{(26)}$. Vitamin A-depleted mice show impaired IgA secretion and protection in mucosal tissues ${ }^{(20)}$. Additionally, most IgA ASC express chemokine receptor CCR10, but IgA ASC from CCR10-deficient mice do not efficiently accumulate in the lactating mammary gland and lead to a significant decrease in milk IgA and faecal IgA of neonatal mice ${ }^{(18)}$. Compared with the increase in milk IgA, $\beta$ carotene supplementation had no clear effect on faecal IgA in the present study. However, because faecal IgA at $14 \mathrm{dpp}$ was 1.6 times higher in mice born to $\beta$-carotenesupplemented mothers, $50 \mathrm{mg} / \mathrm{kg} \quad \beta$-carotene may be slightly useful to enhance faecal $\operatorname{IgA}$ via an increase in milk IgA. Thus, our data imply that $\beta$-carotene supplementation for maternal mice during pregnancy and lactation is effective to increase the number of IgA ASC in mammary gland and of milk IgA during lactation, and that the effects may be mainly due to the RA-mediated immune response because mice efficiently convert $\beta$-carotene to vitamin $\mathrm{A}^{(10)}$.

The pathways leading to milk IgA production are complex, but most IgA in lactating mice is derived from the serum by day 4 of lactation, and IgA synthesis by mammary cells becomes most important during late lactation ${ }^{(27)}$. The mammary gland develops new vasculature during pregnancy, and it is colonised primarily by $\operatorname{IgA}$-containing $\mathrm{B}$ cells during lactation ${ }^{(28)}$. As a result, milk IgA transfers the ability to exclude luminal bacteria from mothers to neonatal mice, and this process is not critically dependent on antibody specificity ${ }^{(16)}$. Compared with IgA concentration at day 7 in neonatal mice, the rapid increase in IgA concentration was observed not only in stomach contents but also in serum, small intestine and faeces at day 14 in the present study. On the other hand, the decreased mRNA expression of IgA C-region in jejunum in neonatal mice born to $\beta$-carotene-supplemented mothers at day 14 may be partly due to the delay in neonatal mucosal immune induction. However, intestinal secretions of IgA in mice at weaning could hardly be found, and then the amounts of IgA rose drastically and reached a maximum concentration at 10 weeks of age ${ }^{(29)}$. Because very few IgA ASC were detected in jejunum and ileum of neonatal mice at day 14 , most IgA in neonatal mice may be derived from milk IgA, and $\beta$-carotene supplementation enhances IgA transfer from maternal milk to neonatal mice.

IgA plasma cells in the mammary gland in mice are derived from the lymphoid cells in gut-associated lymphoid tissue by homing to the mammary gland ${ }^{(17)}$. Homing of ASC to the intestinal mucosa requires the 
expression of integrin $\alpha 4 \beta 7^{(6,14)}$. RA is important to induce $\alpha 4 \beta 7$ and CCR9 on activated T cells, and blocking RA receptors decreases the induction of gut-homing receptors $^{(19)}$. We demonstrated that $\beta$-carotene supplementation increased mRNA expression of IgA C-region and the number of IgA ASC in the ileum during lactation, but in the mammary gland, $\beta$-carotene supplementation only increased the number of IgA ASC. In murine small intestine, mature isolated lymphoid follicles are inductive sites for the immune response, and nodular lymphoid structures are observed in the distal small intestine ${ }^{(30)}$. The numbers of IgA ASC have been shown to be greatly reduced in the small bowel of vitamin A-deficient mice, but retinoids are not absolutely required for IgA production in tissues other than the small intestine ${ }^{(6,20)}$. Supplemental $\beta$ carotene probably increases expression of the chemokine receptor CCR9, and this homing receptor has been shown to be vital in the accumulation of IgA ASC in the intestine. Additionally, maternal IgA ASC primed in the gut homes to the mammary gland during late pregnancy and lactation ${ }^{(17,29)}$, and homing to the lactating mammary gland has been shown to be highly dependent on the expression of CCR10 and $\alpha 4 \beta 1^{(6,31)}$. The data presented in the present paper suggest that $\beta$-carotene supplementation may influence the expression of the chemokine receptor CCR10 and $\alpha 4 \beta 1$ integrin on developing IgA ASC. However, further study is needed to clarify the exact mechanism by which $\beta$-carotene promotes homing from the ileum to the mammary gland.

In conclusion, the present study suggested that supplementation of $\beta$-carotene for maternal mice during pregnancy and lactation is useful for enhancing IgA transfer from maternal milk to neonates owing to the increase in IgA ASC in mammary gland and ileum during lactation.

\section{Acknowledgements}

The present study was supported by a project of the Ministry of Agriculture, Forestry and Fisheries (Tokyo, Japan). Experimental diets were kindly provided by Chubu Shiryo Company Limited (Ohbu, Japan). The authors have no conflict of interest in the present paper. Y. N., M. S., S. I. and S. K. designed the research; Y. N. conducted most of the research; Y. N. and S. K. contributed equally to the discussion and to the writing of the manuscript.

\section{References}

1. Blum JW (2006) Nutritional physiology of neonatal calves. J Anim Physiol Anim Nutr 90, 1-11.

2. Chew BP (1987) Vitamin A and $\beta$-carotene on host defense. J Dairy Sci 70, 2732-2743.

3. Bendich A \& Shapiro SS (1986) Effect of $\beta$-carotene and canthaxanthin on the immune responses of the rat. $J$ Nutr 116, 2254-2262.
4. Bendich A (1989) Carotenoids and the immune response. J Nutr 119, 112-115.

5. Chew BP (1993) Role of carotenoids in the immune response. J Dairy Sci 76, 2804-2811.

6. Mora JR \& von Andrian UH (2009) Role of retinoic acid in the imprinting of gut-homing IgA-secreting cells. Semin Immunol 21, 28-35.

7. Stephensen CB, Moldoveanu Z \& Gangopadhyay NN (1996) Vitamin A deficiency diminishes the salivary immunoglobulin A response and enhances the serum immunoglobulin $G$ response to influenza A virus infection in BALB/c mice. J Nutr 126, 94-102.

8. Kume $S$ \& Toharmat $T$ (2001) Effect of colostral $\beta$-carotene and vitamin $\mathrm{A}$ on vitamin and health status of newborn calves. Livest Prod Sci 68, 61-65.

9. Lotthammer $\mathrm{KH}$ (1979) Importance of $\beta$-carotene for the fertility of dairy cattle. Feedstuffs 52, 36-38.

10. Lee CM, Boileau AC, Boileau TWM, et al. (1999) Review of animal models in carotenoid research. J Nutr 129, 2271-2277.

11. Palozza P, Bellovino D, Simone R, et al. (2009) Effect of $\beta$-carotene-rich tommato lycopene $\beta$-cyclase $(t l c y-b)$ on cell growth inhibition in HT-29 colon adenocarcinoma cells. Brit J Nutr 102, 207-214.

12. Fagarasan $\mathrm{S} \&$ Honjo $\mathrm{T}$ (2003) Intestinal IgA synthesis: regulation of front-line body defenses. Nat Rev Immunol 3, 63-72.

13. Sigmundsdottir H \& Butcher EC (2008) Environmental cues, dendritic cells and the programming of tissue-selective lymphocyte trafficking. Nat Immunol 9, 981-987.

14. Ertesvåg $\mathrm{A}$, Naderi $\mathrm{S} \&$ Blomhoff $\mathrm{HK}$ (2009) Regulation of $\mathrm{B}$ cell proliferation and differentiation by retinoic acid. Semin Immunol 21, 36-41.

15. van der Feltz MJ, de Groot N, Bayley JP, et al. (2001) Lymphocyte homing and Ig secretion in the murine mammary gland. Scand J Immunol 54, 292-300.

16. Harris NL, Spoerri I, Schopfer JF, et al. (2006) Mechanisms of neonatal mucosal antibody protection. J Immunol 177, 6256-6262.

17. Roux ME, McWilliams M, Phillips-Quagliata JM, et al. (1977) Origin of IgA-secreting plasma cells in the mammary gland. J Exp Med 146, 1311-1322.

18. Morteau O, Gerard G, Lu O, et al. (2008) An indispensable role for the chemokine receptor CCR10 in IgA antibodysecreting cell accumulation. J Immunol 181, 6309-6315.

19. Iwata M, Hirakiyama A, Eshima Y, et al. (2004) Retinoic acid imprints gut-homing specificity on $\mathrm{T}$ cells. Immunity $\mathbf{2 1}$, $527-538$.

20. Mora JR, Iwata M, Eksteen B, et al. (2006) Generation of guthoming IgA-secreting B cells by intestinal dendritic cells. Science 314, 1157-1160.

21. Rühl R (2007) Effects of dietary retinoids and carotenoids on immune development. Proc Nutr Soc 66, 458-469.

22. Statistical Analysis Systems (SAS) (1997) SAS/STAT Software: Changes and Enhancement through Release 6.12. SAS Institute Cary, NC.

23. Quigley JD \& Drewry JJ (1998) Nutrient and immunity transfer from cow to calf pre- and postcalving. J Dairy Sci $\mathbf{8 1}$ 2779-2790.

24. Johnson MS, Thomson SC \& Speakman JR (2001) Limits to sustained energy intake. I. Lactation in the laboratory mouse Mus musculus. J Exp Biol 204, 1925-1935.

25. Jiang HQ, Bos NA \& Cebra JJ (2001) Timing, localization, and persistence of colonization by segmented filamentous bacteria in the neonatal mouse gut depend on immune status of mothers and pups. Infect Immun 69 , $3611-3617$. 
26. Garcia AL, Rühl R, Herz U, et al. (2003) Retinoid- and carotenoid-enriched diets influence the ontogenesis of the immune system in mice. Immunology 110, 180-187.

27. Van del Heijden PJ, Bianchi ATJ, Stok W, et al. (1988) Background (spontaneous) immunoglobulin production in the murine small intestine as a function of age. Immunology 65, 243-248.

28. Halsey JF, Mitchell C, Meyer R, et al. (1982) Metabolism of immunoglobulin A in lactating mice: origins of immunoglobulin A in milk. Eur J Immunol 12, 107-112.

29. Tanneau GM, Hibrand-Saint Oyant L, Chevaleyre CC, et al. (1999) Differential recruitment of T- and IgA B-lymphocytes in the developing mammary gland in relation to homing receptors and vascular addressins. J Histochem Cytochem 47, 1581-1592.

30. Lorenz RG, Chaplin DD, McDonald KG, et al. (2003) Isolated lymphoid follicle formation is inducible and dependent upon lymphotoxin-sufficient B lymphocytes, lymphotoxin beta receptor, and TNF receptor I function. I Immunol 170, 5475-5482.

31. Wilson E \& Butcher EC (2003) CCL28 controls immunoglobulin IgA plasma cell accumulation in the lactating mammary gland and IgA antibody transfer to the neonate. J Exp Med 200, 805-809. 